\title{
Audit Sistem Pendataan Keluarga Menggunakan Pendekatan Framework COBIT 5 Pada Domain DSS (Studi Kasus: BKKBN Propinsi Jawa Barat)
}

\author{
Angga Maulana Nurhuda ${ }^{1 *}$, Ervan Philipus ${ }^{2}$, Ivan Gunawan ${ }^{3}$ \\ 1,2,3Program Studi Sistem Informasi, STMIK LIKMI, Bandung, Jawa Barat \\ Email: ${ }^{1 *}$ anggaif06@gmail.com, ${ }^{2}$ ervanphilipus@yahoo.co.id, ${ }^{3}$ ivangunwn@gmail.com
}

(Naskah masuk: 7 Jan 2021, direvisi: 9 Feb 2021, 2 Mar 2021, diterima: 5 Mar 2021)

\begin{abstract}
Abstrak
Peran sistem pendataan keluarga dalam rangka mendukung pencapaian program BANGGAKENCANA pada BKKBN Propinsi Jawa Barat adalah untuk menyediakan data dasar sebagai perencanaan strategis, peta kerja, maupun pemetaan mekanisme operasional menjadi krusial untuk menopang keberhasilan program. Untuk memastikan delivery produk, layanan, dan dukungan yang dihasilkan perlu dilakukan evaluasi sehingga dapat menghasilkan tata kelola sistem pendataan keluarga yang lebih optimal. Penelitian ini bertujuan untuk memperoleh ukuran capability level proses TI saat ini kemudian dibandingkan dengan yang diharapkan sehingga dapat diperoleh kesenjangan guna penyusunan rekomendasi yang dapat diimplementasikan pada Siklus Sistem Pendataan Keluarga Tahun 2021 dengan menggunakan kerangka kerja COBIT 5. Data yang diperoleh bersumber dari responden yang berwenang dan kompeten berdasarkan pemetaan diagram RACI pada COBIT 5. Dari hasil penelitian, diketahui bahwa dari 6 proses terpilih pada domain DSS terdapat 4 proses yang mencapai level 1 (performed) dan 2 proses yang berhasil mencapai level 2 (managed process). Tingkat kemampuan manajemen TI yang diharapkan berada pada level 3 sehingga GAP muncul di semua domain yang bermakna saat ini organisasi belum sepenuhnya mengimplementasikan proses yang ditetapkan untuk mencapai tujuan proses. Dari seluruh rangkaian penelitian tersebut dapat disimpulkan bahwa diperoleh nilai level kapabilitas sebesar 1,33 dan terdapat GAP sebesar 1,67 untuk mencapai level yang diharapkan. Dalam penelitian ini disampaikan rekomendasi untuk meningkatkan kapabilitas proses sehingga BKKBN Propinsi Jawa Barat dapat mencapai tingkat kapabilitas yang diharapkan.
\end{abstract}

Kata Kunci: Audit SI/TI, COBIT 5, Pendataan Keluarga, Analisis GAP

\section{Auditing of Family Data System Using COBIT 5 Framework Approach in DSS Domain (Case Study: BKKBN of West Java Province)}

\begin{abstract}
Role of the family data system, in order to support the achievement of the BANGGAKENCANA program at the BKKBN of West Java Province, is to provide basic data for strategic planning, work maps, and mapping of operational mechanisms which are crucial to sustain the success of the program. To ensure the delivery of products, services, and the resulting support, it is necessary to evaluate so that it can produce the optimal governance of family data system. This study aims to obtain a measure of the current and expected level of IT process capability and the preparation of recommendations that can be implemented in family data system 2021 using the COBIT 5 framework. The obtained data are sourced from authorized and competent respondents based on the mapping of the RACI diagram on COBIT 5. From the research results, it is known that from the 6 selected domains, there are 4 domains IT process that succeeded in reaching level 1 (performed) and 2 domains IT process that succeeded in reaching level 2 (managed). The expected level of IT management capability is at level 3 so that GAP appears in all domains which means currently the organization has not fully implemented the defined processes to achieve the objectives of the process. From all the entire studies, can be concluded that the capability level value is 1.33 and there is GAP 1.67 to reach the expected level. In this study, recommendations are prepared which aim to improve the capability of the process so that the BKKBN of West Java Province can achieve the expected level of capability.
\end{abstract}

Keywords: IS/IT Audit, COBIT 5, Family Data, GAP Analysis 


\section{PENDAHULUAN}

Perkembangan data yang dinamis di era sekarang, baik dalam skala makro maupun mikro tidak dapat terlepas dari berbagai media maupun sarana dan mekanisme yang digunakan oleh organsasi pada proses pengelolaannya. Hal ini dipastikan akan sangat memberikan dampak terhadap kebijakan dan strategi yang kemudian akan diterapkan di masa mendatang sehingga data sebaiknya digunakan sebagai gambaran umum atas kondisi di lapangan. Dengan demikian diharapkan organisasi dapat memetakan perencanaan, kebijakan, strategi, dan target yang selaras dengan visi, misi, dan tupoksi yang diemban. Pemanfaatan data yang optimal diharapkan dapat mempermudah organisasi dalam menyisir permasalahan dan hambatan yang mungkin timbul dalam rangka mencapai tujuan organisasi, baik dari sisi internal maupun eksternal. Di samping itu, mekanisme pengumpulan data menjadi hal yang krusial dalam menunjang tingkat validitas sebuah data yang kemudian berdampak pada seberapa jauh pemanfaatan data yang telah dikumpulkan. Selain itu, pengolahan data juga menjadi faktor yang harus diperhatikan oleh seluruh stakeholder yang terlibat.

Berdasarkan grafik yang disampaikan oleh Direktorat Pelaporan dan Statistik, Badan Kependudukan dan Keluarga Berencana Nasional (BKKBN) dengan pembanding data dari Pelaporan Rutin DALAP (Pengendalian Lapangan), Survei Demografi Kependudukan Indonesia (SDKI), dan target yang ditetapkan BKKBN RI pada variabel CPR (Contraceptive Pre-Valency Rate) yaitu peserta KB aktif dibanding pasangan usia subur terdapat selisih antar sumber data yang dibandingkan. Pada Gambar 1 dapat dilihat bahwa Propinsi Jawa Barat menunjukan adanya selisih data dari berbagai sumber yang kemudian menimbulkan asumsi anomali data yang dihasilkan. Tujuan utama BKKBN Propinsi Jawa Barat adalah untuk mewujudkan laju pertumbuhan penduduk yang seimbang dengan angka TFR (Total Fertility Rate) 2,15 dengan makna seluruh pasangan usia subur memiliki rerata 23 anak. Untuk mencapai TFR tersebut diperlukan data yang valid sebagai data dasar sekaligus hasil pengukuran sehingga harus dapat dipastikan sistem pendataan keluarga mengakomodir terhadap tujuan organisasi terutama dari sisi delivery data yang dihasilkan, service yang disediakan, dan support data yang muncul guna mencapai keselarasan tujuan organisasi dengan sistem yang digunakan.

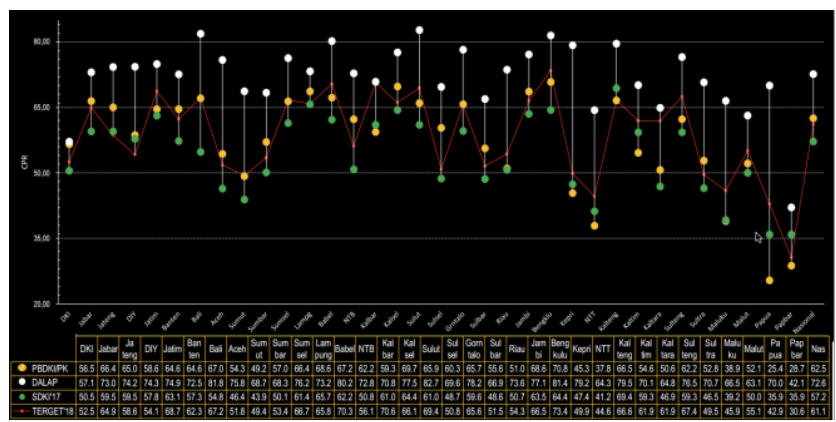

Gambar 1. Output Hasil Pendataan Keluarga Dibanding Sumber Data Lain [1]
Penelitian yang dilakukan diharapkan dapat mengetahui Capability Level serta memghasilkan rekomendasi berupa perbaikan pada bidang teknologi informasi serta analisis GAP dari hasil evaluasi. Oleh karena itu penulis perlu mengidentifikasi masalah yang berkaitan dengan sistem Pendataan Keluarga (PK) mengenai seberapa besar tingkat kapabilitas sistem PK dengan memanfaatkan framework COBIT 5, bagaimana manajemen layanan sistem diterapkan pada sistem yang ada, dan bagaimana manajemen sistem diterapkan. Sedangkan penelitian dimaksud bertujuan untuk menghasilkan pencapaian tingkat kapabilitas dan rekomendasi dari hasil analisis GAP untuk kemudian menyajikan rekomendasi perbaikan tata kelola sistem yang dapat diimplementasikan pada siklus PK 2021.

\section{LANDASAN TEORI}

Untuk mengukur tingkat efektifitas dan efisiensi mekanisme opersional yang diimplementasikan pada organisasi diperlukan sebuah proses auditing guna menjaga dan menyelaraskan dengan visi misi perusahaan yang telah ditetapkan sehingga kegiatan-kegiatan yang tidak sejalan tersebut dapat dideteksi dan dijadikan sebagai acuan dalam perbaikan sistemik dalam mencapai tujuan organisasi.

\section{A. Audit Sistem Informasi}

Dalam bukunya Swastika \& Putra menyatakan bahwa definisi audit sistem informasi merupakan proses pengumpulan dan pengevaluasian bukti untuk menentukan apakah sistem komputer dapat melindungi aset, memelihara integritas data, memungkinkan tujuan organisasi untuk dicapai secara efektif, dan menggunakan sumber daya secara efisien [2].

Dalam literatur lain, Andry menyatakan bahwa audit sistem informasi merupakan suatu pengevaluasian untuk mengetahui bagaimana tingkat kesesuaian antara aplikasi sistem informasi dengan prosedur yang telah ditetapkan dan mengetahui apakah suatu sistem informasi telah didesain dan diimplementasikan secara efektif, efisien, dan ekonomis, memiliki mekanisme pengamanan aset yang memadai, serta menjamin integritas data yang memadai [3].

\section{B. COBIT}

Framework COBIT juga merupakan metode standar internasional yang biasa digunakan dalam pengendalian/kontrol pada bidang teknologi informasi dengan memberikan kerangka kerja dan kontrol terhadap teknologi informasi. COBIT adalah kerangka kerja tata kelola TI dan audit SI yang diterima secara luas dan mewakili kerangka kerja 'umbrella' untuk menerapkan kebijakan dan prosedur tata kelola TI dan untuk melakukan audit TI. [4]. Beberapa alasan penting mengapa audit TI perlu dilakukan, antara lain: 1. Kerugian akibat kehilangan data; 2. Kesalahan dalam pengambilan keputusan; 3. Risiko kebocoran data; 4. Penyalahgunaan komputer; 5. Kerugian akibat kesalahan proses perhitungan; 6 . Tingginya nilai investasi perangkat keras dan perangkat lunak komputer [5]. 
COBIT memiliki 5 (lima) kerangka kerja utama yang dijelaskan sebagai berikut [6]:

1. Evaluate, Direct, and Monitor (EDM): Domain ini mencakup terhadap proses pengelolaan yang memiliki keterkaitan dengan pengelolaan sasaran stakeholder, nilai pengiriman, optimisasi resiko dan sumber daya, yang mencakup praktek dan aktivitas yang ditujukan terhadap proses evaluasi pilihan strategi, pemberian pengarahan IT, dan proses monitorisasi outcome.

2. Align, Plan and Organise (APO): Domain ini mencakup strategi dan taktik, domain ini juga berfokus terhadap proses identifikasi cara terbaik pengkontribusian IT dalam mencapai sasaran bisnis. Realisasi dari visi strategi harus direncanakan, dikomunikasikan, dan dikelola untuk prespektif yang berbeda. Pengorganisasian yang benar dan infrastruktur teknologi harus ditempatkan di tempat yang benar.

3. Build, Acquire, and Implement (BAI): Domain ini berperan dalam pemberian solusi dan menyediakan pelayanan. Dalam perealisasian strategi IT, solusi IT perlu diidentifikasi, dikembangkan atau didapatkan, begitupun diimplementasikan dan diintegrasikan pada proses bisnis. Perubahan dan maintenance dari sistem yang ada juga pada lingkup domain ini, untuk memastikan solusi sesuai dengan tujuan bisnis.

4. Deliver, Service and Support (DSS): Domain DSS berfokus terhadap aktual delivery and support of required services, yang temasuk service delivery, pengelolaan atas keamanan dan kontinuitas, layanan bantuan untuk user, serta manajemen atas data dan fasilitas operasional.

5. Monitor, Evaluate and Assess (MEA): berperan dalam tindakan monitoring semua proses sehingga dapat memastikan pengarahan yang diberikan ditaati. Semua proses IT harus diperiksa secara regular tiap waktu untuk memastikan kebutuhan kualitas dan ketaatan dengan kebutuhan pengendalian. Domain mengajukan manajemen kinerja, monitor dari internal, ketaaatan dan tata kelola.

Domain Deliver, Service, and Support (DSS) dipilih karena paling sesuai untuk objek suatu sistem yang telah direncanakan (plan), dibangun (build), dan sekarang sedang dijalankan (run). Adapun domain lain seperti Align, Plan, and Organize (APO) akan lebih sesuai jika diterapkan pada tata kelola TI yang belum digunakan [7]. Selain itu, domain Monitor, Evaluate and Asses (MEA) dapat digunakan jika tata kelola TI telah dibangun dan telah berjalan, serta pelaksanaan monitoring secara rutin dilakukan oleh pihak internal, mengingat monitoring dengan audit mempunyai intensitas berbeda, monitoring lebih sering dilakukan dalam jangka waktu tertentu daripada audit sehingga MEA akan lebih sesuai untuk monitoring, bukan audit [8]. Mengacu pada uraian diatas, sistem pendataan keluarga saat ini dalam kondisi area run yaitu sedang berjalan untuk mengirimkan layanan, melayani permintaan, dan mendukung keberlanjutan tata kelola TI, maka domain DSS adalah domain terpilih karena hal-hal tersebut sesuai dan berada di dalam domain DSS.

\section{Diagram RACI}

Dalam kerangka kerja COBIT, RACI diperlukan untuk menunjukan peran dan tanggung jawab dari suatu fungsi dalam sebuah struktur organisasi terhadap sebuah aktivitas IT process goal tertentu. Penggunaan RACI memungkinkan manajer dari tingkat organisasi atau program yang sama atau berbeda untuk berpartisipasi aktif dalam diskusi yang terfokus dan sistematis mengenai deskripsi proses terkait dengan tindakan yang harus dilakukan dalam rangka untuk mendukung pencapaian tujuan organisasi. Seluruh IT process goal menerapkan RACI pada setiap aktivitas di dalamnya yang berfungsi untuk mendukung kesuksesan proses TI pada kelima domain yang ada.

Metode RACI akan efektif mempermudah target yang sudah ditentukan serta meningkatkan kinerja dan efisiensi. RACI mempermudah pembuatan keputusan sehingga mampu memberi informasi workload karyawan yang memiliki tugas spesifik. RACI memiliki peran untuk menyelesaikan tugas ketika melenceng dari target. RACI akan dengan mudah menunjukkan pihak yang terlibat dan bertanggung jawab pada kekurangan tersebut. Diagram RACI merupakan salah satu tools bagi auditor untuk mengidentifikasi responden yang memiliki tanggungjawab serta kompetensi untuk menjawab pertanyaan-pertanyaan yang diajukan duna untuk mengumpulkan bukti.

Terdapat 26 role atau peran pada COBIT 5 yang digunakan dalam RACI. Semua role atau peran tersebut kemudian dipetakan sesuai dengan peran yang ada pada organisasi dengan mengacu pada Key Management Practice (KMP). Untuk menentukan responden mana yang berwenang dan mampu, dalam penelitian ini diagram RACI digunakan untuk mendefinisikan apa dan kepada siapa harus dilimpahkan, terdiri dari [9]:

$\mathrm{R}: \begin{aligned} & \text { Responsible, pihak bertanggungjawab untuk } \\ & \text { memastikan aktivitas tersebut berhasil } \\ & \text { dilaksanakan. }\end{aligned}$

Accountable, pihak yang memiliki kewenangan A : untuk menyetujui dan menerima pelaksanaan aktivitas tertentu.

C : Consulted, pihak yang pendapatnya dibutuhkan dalam aktivitas terkait.

Informed, pihak yang selalu menjaga kemajuan I : informasi atas aktivitas yang dilakukan (komunikasi arah).

\section{Capability Model}

Proses capability model digunakan untuk mengukur kematangan IT enterprise yang diadopsi dari ISO/IEC 15504 sebagai standar proses penilaian. Model ini menyediakan pengukuran performansi dari proses-proses pada area governance atau manajemen dan melakukan peningkatan pada area-area yang telah diidentifikasi. Terdapat 6 level kapabilitas proses yang bisa dicapai termasuk incomplete 
process jika prakteknya tidak tercapai sesuai dengan tujuan seperti terlihat pada Gambar 2.

\begin{tabular}{ll}
\hline Process Attribute ID & Capability Levels and Process Attributes \\
\hline & Level 0: Incomplete process \\
\hline PA 1.1 & Level 1: Performed process \\
\hline PA 2.1 & Process performance \\
\hline PA 2.2 & Level 2: Managed process \\
\hline PA 3.1 & Performance management \\
\hline PA 3.2 & Work product management \\
\hline & Level 3: Established process \\
\hline PA 4.1 & Process definition \\
\hline PA 4.2 & Process deployment \\
\hline & Level 4: Predictable process \\
\hline PA 5.1 & Process measurement \\
\hline PA 5.2 & Process control \\
\hline
\end{tabular}

Gambar 2. Proses Capability Model [10]

\section{METODE PENELITIAN}

Dalam melaksanakan kegiatan penelitian dimaksud, penulis menggunakan Framework Control Objectives for Information and Related Technology (COBIT) versi 5 (lima) dengan memanfaatkan Domain DSS (Deliver, Service and Support) melalui tahapan pada Gambar 3 sebagai berikut:

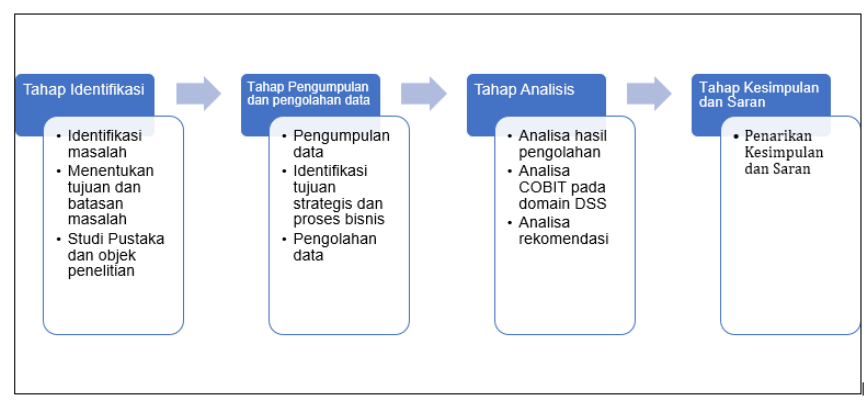

Gambar 3. Tahapan Penelitian

\section{A. Identifikasi}

Pada tahap identifikasi terdapat proses atau aktivitas berupa kegiatan identifikasi masalah untuk mengetahui fenomena apa yang dapat diangkat/diteliti sehingga dapat menentukan tujuan dan batasan penelitian, melakukan studi pendahuluan dengan studi pustaka berdasarkan buku maupun literatur lain yang relevan dan dapat digunakan, dan studi objek penelitian yang dilakukan dengan melaksanakan meeting stakeholder dalam mengidentifikasi kebutuhan untuk mendiskusikan tujuan dari perusahaan dan dilakukan pemetaan dengan memanfaatkan framework COBIT 5.

Pengumpulan dan pemrosesan bukti, yaitu tahapan pengumpulan dan pemrosesan informasi dilakukan secara hierarki untuk mendapatkan keselarasan antara tujuan perusahaan dan tujuan terkait TI untuk menentukan proses yang dipilih di COBIT dengan tahapan berikut:

1. Identifikasi Tujuan, Arahan Strategis dan Proses Bisnis

Data yang terkumpul melalui metode yang sudah dijelaskan sebelumnya mengenai hasil identifikasi tujuan, arahan strategis dan proses bisnis kemudian dilakukan pemetaan kepada proses COBIT 5 yang terdiri:

a) Enterprise Goals (EG), Hasil pemetaan yang telah dilakukan antara Enterprise Goals dengan Sasaran Strategis BKKBN Propinsi Jawa Barat yang telah dilakukan menyatakan bahwa terdapat Enterprise Goals terpilih dengan menggunakan dimensi BSC (Balance Scorecard) adalah EG1, EG4, EG6, EG7, EG9, EG11, EG12, EG14, EG15, and EG16.

b) IT-Related Goals (ITG), Hasil pemetaan antara EG terpilih dengan ITG menghasilkan hampir seluruh ITG diproses ke tahap selanjutnya, hanya proses ITG-17 yang tidak dapat diakomodir.

c) Process Control

Nilai Proses $=((\Sigma \mathrm{P} * 2)+\Sigma \mathrm{S}) /(2 *$ jumlah ITG $))$

Pada Tabel 1 dapat dilihat nilai proses hasil pemetaan Process Control dengan IT-Related Goals sehingga dapat ditentukan domain mana dalam DSS yang dapat diproses dalam tahapan selanjutnya yaitu Domain DSS01- DSS06 disebabkan oleh nilai proses dari masing-masing proses adalah $>0,15$ sehingga menunjukan tingkat urgenitas dari tiap nilai proses yang ada.

Tabel 1. Pemetaan Process Control Dengan IT-Related Goals

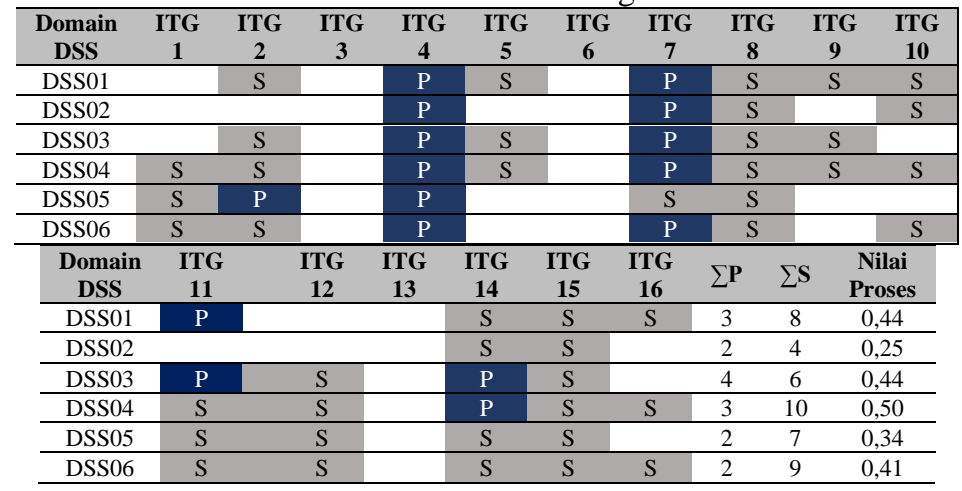


2. Hasil Pemetaan Diagram RACI

Penentuan peran dan deskripsi kerja ditentukan dengan menggunakan diagram RACI sesuai dengan aktivitas COBIT pada setiap proses dalam domain DSS. Penentuan peran dan deskripsi kerja didasarkan pada RACI chart yang termasuk kategori responsible (R) atau accountable (A) [9]. Pemilihan kategori $\mathrm{R}$ atau $\mathrm{A}$ yang digunakan dalam penentuan peran dan deskripsi kerja didasarkan pada masing-masing deskripsi peran dan tanggung jawab RACI chart. Untuk mengerucutkan perolehan data ataupun bukti kondisi existing terkait sistem pendataan keluarga, diperlukan pengetahuan dan kompetensi yang mendalam sehingga informasi yang dihasilkan valid dan terukur. Adapun hasil pemetaan role atau peran yang digunakan dapat dilihat pada Tabel 2.

Tabel 2. Pemetaan Role COBIT dan Role Organisasi

\begin{tabular}{ll}
\multicolumn{1}{c}{ Role Pada COBIT } & \multicolumn{1}{c}{ Role Pada BKKBN } \\
\hline Business Process Owner & DITLAPTIK \\
\hline Business Executive & DITTEKDA \\
\hline Chief Operating Officer & Koordinator ADPIN \\
\hline Business Continuity Manager & Koordinator ADPIN \\
\hline Chief Information Officer & $\begin{array}{l}\text { Subkor Data dan } \\
\text { Informasi }\end{array}$ \\
\hline Head of Architecture & Subdit SABD \\
\hline Head IT Operations & Subkor Data dan \\
\hline $\begin{array}{l}\text { Information Security } \\
\text { Manager }\end{array}$ & Subdit ITI \\
\hline Chief Information Security & Prakom Ahli \\
\hline Officer & Subdit SABD \\
\hline Service Manager & Subdit SABD \\
\hline Chief Excecutive Officer & DITTEKDA \\
\hline Chief Financial Officer & Subbag Keuangan dan \\
\hline
\end{tabular}

3. Pengumpulan Data

Dalam pelaksanaan kegiatan audit pada sistem pendataan keluarga diperlukan informasi kondisi existing yang diterapkan sehingga kemudian pada tahap berikutnya yaitu pada tahap analisis dapat diperoleh grade untuk dilakukan analisis GAP. Berikut hasil pengumpulan data berupa kondisi existing dengan mengacu pada self assessment template berdasarkan COBIT yang disusun terhadap setiap proses dan RACI [10].

\section{Analisis}

Tahapan analisis pada penelitian ini dibagi kedalam 3 tahap yakni: analisis capability level, analisis GAP, dan rekomendasi untuk mengejar celah yang diperoleh dalam rangka mencapai tingkat kapabilitas yang diharapkan. Setiap atribut dinilai menggunakan standar ISO/IEC 15504. Skala dimaksud adalah [7]: 1) N (Not Achieved) - rentang capaian 0 to $15 \%$ yang bermakna masih sedikit atau bahkan belum terdapat ketercapaian sama sekali pada proses yang dinilai pada atribut yang ditentukan. 2) P (Partially Achieved) dengan rentang $>15 \%$ to $50 \%$ bermakna Terdapat beberapa ketercapaian pada proses yang dinilai dari atribut yang ditentukan, namun belum signifikan. 3) L (Largely Achieved) - dengan rentang > 50\% to $85 \%$ yang bermakna Terdapat ketercapaian yang signifikan pada proses yang dinilai dari atribut yang ditentukan. 4) F (Fully Achieved) - dengan rentang $>85 \%$ to $100 \%$ yang bermakna Terdapat ketercapaian secara penuh pada proses yang dinilai dari atribut yang ditentukan.

\section{Kesimpulan dan Saran}

Pada tahap kesimpulan dan saran yang merupakan tahapan terakhir pada penelitian ini berisi rangkuman dari proses dan hasil penelitan yang dituangkan dalam poin kesimpulan serta masukan atau rekomendasi untuk tindak lanjut maupun penelitian lanjutan yang akan dilakukan kemudian.

\section{ANALISIS DAN PEMBAHASAN}

Pada tahap analisis dilakukan penilaian berdasarkan capability level pada COBIT 5 dengan mengacu pada hasil process control terhadap IT Related Goals yang menyimpulkan terdapat 6 (enam) proses atau seluruh proses pada domain DSS perlu dijadikan sebagai cakupan proses audit untuk menentukan capaian masing-masing capability level, analisis GAP, dan rekomendasi yang perlu dipenuhi untuk mencapai ekspektasi level yang ditentukan. Seluruh proses yang dianalisis menggunakan metode observasi dan wawancara untuk mendapatkan informasi yang valid dengan mengacu pada Process Assessment Model (PAM) pada COBIT. Adapun harapan dari tingkat kapabilitas yang diharapkan oleh BKKBN Provinsi Jawa Barat adalah pada level 3 yaitu Estabhlised Process.

\section{Capability level}

Aktivitas analisis capability level merupakan kegiatan pengukuran level terhadap setiap domain DSS dimana domain tersebut digunakan oleh penulis sebagai batasan dalam kegiatan penelitian ini.

\section{a. DSS01 - Mengelola Operasi}

Berdasarakan informasi maupun bukti terhadap setiap sub proses pada masing-masing proses yang ada pada DSS01 mengenai pengelolaan operasional yang diperoleh dari responden dengan mengacu pada skala penilaian standar ISO/IEC 15504 dijelaskan pada Tabel 3 berikut.

Tabel 3. Hasil Penilaian Capability Level 1 Proses DSS01

\begin{tabular}{rlcc}
\hline $\begin{array}{r}\text { ID Sub } \\
\text { Proses }\end{array}$ & Nama Sub Proses & Skor & Kondisi \\
\hline DSS01.01 & $\begin{array}{l}\text { Perform operational } \\
\text { procedures }\end{array}$ & $100 \%$ & $\mathrm{~F}$ \\
\hline DSS01.02 & $\begin{array}{l}\text { Manage outsourced } \\
\text { IT services }\end{array}$ & $100 \%$ & $\mathrm{~F}$ \\
\hline DSS01.03 & $\begin{array}{l}\text { Monitor IT } \\
\text { Infrasucture }\end{array}$ & $67 \%$ & $\mathrm{~L}$ \\
\hline
\end{tabular}




\begin{tabular}{llrl}
\hline DSS01.04 & $\begin{array}{l}\text { Manage the } \\
\text { Environment }\end{array}$ & $100 \%$ & $\mathrm{~F}$ \\
\hline DSS01.05 & Manage facilities & $100 \%$ & $\mathrm{~F}$ \\
\hline Rerata Skor & & $93,40 \%$ & $\mathrm{~F}$ \\
\hline
\end{tabular}

Tabel 4. Ringkasan Capaian Capability Level Proses DSS01

\begin{tabular}{crrrr}
\hline $\begin{array}{c}\text { DSS01 } \\
\text { Mengelola } \\
\text { Operasi }\end{array}$ & Level 0 & Level 1 & \multicolumn{2}{c}{ Level 2 } \\
\cline { 2 - 5 } Rating & $100 \%$ & $93,40 \%$ & $100 \%$ & $92,50 \%$ \\
\hline
\end{tabular}

Tabel 4 menjelaskan bahwa capaian capability level pada level 1 memperoleh skor 93,40\% atau fully achieved sehingga pada proses DSS01 bermakna bahwa implementasi proses pengelolaan operasional telah berjalan hampir seluruhnya sehingga dapat dinyatakan proses DSS pada level 1 sudah tercapai. Oleh karena itu, pengukuran pada DSS01 dapat dilanjutkan ke level 2 yang juga memperoleh penilaian $100 \%$ atau fully achieved pada PA 2.1 yakni dari sisi performance management bermakna bahwa pada seluruh indikator tersebut sudah terpenuhi. Sedangkan pada PA 2.2 memperoleh persentase sebesar $92,50 \%$ atau kembali fully achieved yang mengindikasikan hampir seluruh proses pada atribut tersebut sudah terpenuhi.

b. DSS02 - Mengelola Layanan Permintaan dan Insiden

Berdasarkan informasi maupun bukti terhadap setiap sub proses pada masing-masing proses yang ada pada DSS02 mengenai pengelolaan layanan permintaan dan insiden yang diperoleh dari responden dijelaskan pada Tabel 5 berikut.

Tabel 5. Hasil Penilaian Capability Level 1 Proses DSS02

\begin{tabular}{|c|c|c|c|}
\hline $\begin{array}{l}\text { ID Sub } \\
\text { Proses }\end{array}$ & Nama Sub Proses & Skor & Kondisi \\
\hline DSS02.01 & $\begin{array}{l}\text { Define incident and } \\
\text { service request } \\
\text { classification } \\
\text { schemes }\end{array}$ & $67 \%$ & $\mathrm{~L}$ \\
\hline DSS02.02 & $\begin{array}{l}\text { Record, classify and } \\
\text { prioritise requests } \\
\text { and incidents }\end{array}$ & $100 \%$ & $\mathrm{~F}$ \\
\hline DSS02.03 & $\begin{array}{l}\text { Verify, approve and } \\
\text { fulfil service } \\
\text { requests }\end{array}$ & $0 \%$ & $\mathrm{~N}$ \\
\hline DSS02.04 & $\begin{array}{l}\text { Investigate, } \\
\text { diagnose and } \\
\text { allocate incidents }\end{array}$ & $100 \%$ & $\mathrm{~F}$ \\
\hline DSS02.05 & Manage facilities & $100 \%$ & $\mathrm{~F}$ \\
\hline DSS02.06 & $\begin{array}{l}\text { Resolve and recover } \\
\text { from incidents }\end{array}$ & 100 & $\mathrm{~F}$ \\
\hline DSS02.07 & $\begin{array}{l}\text { Track status and } \\
\text { produce }\end{array}$ & $0 \%$ & $\mathrm{~N}$ \\
\hline Rerata Skor & & $67,67 \%$ & $\mathrm{~L}$ \\
\hline
\end{tabular}

Tabel 6. Ringkasan Capaian Capability Level Proses DSS02

\begin{tabular}{ccccc}
\hline DSS02 & Level 0 & Level 1 & Level 2 \\
\cline { 2 - 5 } $\begin{array}{c}\text { Mengelola } \\
\text { Layanan } \\
\text { Permintaan } \\
\text { dan Insiden }\end{array}$ & & & PA 2.1 & PA 2.2 \\
\hline Rating & $100 \%$ & $66,67 \%$ & \\
\hline
\end{tabular}

Tabel 6 menjelaskan bahwa capaian capability level pada level 1 memperoleh skor $66,67 \%$ atau largely achieved sehingga proses DSS02 bermakna bahwa organisasi telah mengetahui adanya aktivitas teknologi informasi dalam organisasinya dalam hal pengelolaan permintaan layanan dan insiden. implementasi proses pengelolaan permintaan layanan dan insiden sebagian besar telah berjalan namun memerlukan perbaikan yang signifikan untuk mencapai harapan yang ditetapkan.

\section{c. DSS03 - Mengelola Masalah}

Memastikan bahwa semua permasalahan bisa dikendalikan dan mencegah hal sserupa kembali terjadi serta memberikan rekomendasi perbaikan. Pengelolaan masalah yang muncul dapat dideteksi dengan validasi yang sudah diterapkan secara sistemik. Namun hal tersebut tidak melalui tahapan procedural untuk menampakkan laporan akar permasalahan dan status penyelesaian masalah sehingga penyelesaian masalah tidak sepenuhnya terdokumentasikan dengan baik dengan skor seperti terlihat pada Tabel 7 .

Tabel 7. Hasil Penilaian Capability Level 1 Proses DSS03

\begin{tabular}{clcc}
\hline $\begin{array}{c}\text { ID Sub } \\
\text { Proses }\end{array}$ & Nama Sub Proses & Skor & Kondisi \\
\hline DSS03.01 & $\begin{array}{l}\text { Identify and classify } \\
\text { problems }\end{array}$ & $80 \%$ & $\mathrm{P}$ \\
\hline DSS03.02 & $\begin{array}{l}\text { Investigate and } \\
\text { diagnose problems }\end{array}$ & $0 \%$ & $\mathrm{~N}$ \\
\hline DSS03.03 & Raise known errors & $50 \%$ & $\mathrm{~L}$ \\
\hline DSS03.04 & $\begin{array}{l}\text { Resolve and close } \\
\text { problems }\end{array}$ & $50 \%$ & $\mathrm{~N}$ \\
\hline DSS03.05 & $\begin{array}{l}\text { Perform proactive } \\
\text { and close problems }\end{array}$ & $0 \%$ & $\mathrm{~N}$ \\
\hline Rerata skor & & $36,00 \%$ & $\mathrm{P}$ \\
\hline
\end{tabular}

Tabel 8. Ringkasan capaian capability level proses DSS03

\begin{tabular}{|c|c|c|c|c|}
\hline \multirow{2}{*}{$\begin{array}{c}\text { DSS03 } \\
\text { Mengelola } \\
\text { Masalah }\end{array}$} & \multirow[t]{2}{*}{ Level 0} & \multirow[t]{2}{*}{ Level 1} & \multicolumn{2}{|c|}{ Level 2} \\
\hline & & & $\begin{array}{l}\text { PA } \\
2.1\end{array}$ & PA 2.2 \\
\hline Rating & $100 \%$ & $36,00 \%$ & & \\
\hline
\end{tabular}

Tabel 8 menjelaskan bahwa Capaian capability level pada level 1 memperoleh skor $36,00 \%$ atau partially achieved sehingga pada proses DSS03 bermakna bahwa organisasi 
belum mengetahui mekanisme pengelolaan masalah dengan baik.

\section{d. DSS04 - Mengelola Keberlanjutan}

Berperan dalam pengelolaan keberlanjutan yang diperoleh dari responden. Hasil penilaian terlihat pada Tabel 9.

Tabel 9. Hasil Penilaian Capability Level 1 Proses DSS04

\begin{tabular}{clcc}
\hline \multicolumn{1}{c}{$\begin{array}{c}\text { ID Sub } \\
\text { Proses }\end{array}$} & $\begin{array}{l}\text { Nama Sub Proses } \\
\text { DSS04.01 }\end{array}$ & Skor & Kondisi \\
\hline & $\begin{array}{l}\text { Define the business } \\
\text { continuity policy, } \\
\text { objectives and scope }\end{array}$ & $67 \%$ & $\mathrm{~L}$ \\
\hline DSS04.02 & $\begin{array}{l}\text { Maintain a } \\
\text { continuity strategy }\end{array}$ & $67 \%$ & $\mathrm{~L}$ \\
\hline & $\begin{array}{l}\text { Develop and } \\
\text { implement a } \\
\text { business continuity } \\
\text { response }\end{array}$ & $100 \%$ & $\mathrm{~F}$ \\
\hline DSS04.04 & $\begin{array}{l}\text { Exercise, test, and } \\
\text { review the BCP }\end{array}$ & $67 \%$ & $\mathrm{~L}$ \\
\hline DSS04.05 & $\begin{array}{l}\text { Review, maintain } \\
\text { and improve the } \\
\text { continuity plan }\end{array}$ & $100 \%$ & $\mathrm{~F}$ \\
\hline DSS04.06 & $\begin{array}{l}\text { Conduct continuity } \\
\text { plan training }\end{array}$ & $100 \%$ & $\mathrm{~F}$ \\
\hline DSS04.07 & $\begin{array}{l}\text { Manage backup } \\
\text { arrangements }\end{array}$ & $100 \%$ & $\mathrm{~F}$ \\
\hline DSS04.08 & $\begin{array}{l}\text { Conduct } \\
\text { postresumption } \\
\text { review }\end{array}$ & $100 \%$ & $\mathrm{~F}$ \\
\hline Rerata skor & \begin{tabular}{l}
$87,63 \%$ \\
\hline
\end{tabular} & $\mathrm{F}$ \\
\hline
\end{tabular}

Tabel 10. Ringkasan Capaian Capability Level Proses DSS04

\begin{tabular}{crrrr}
\hline DSS04 & Level 0 & Level 1 & \multicolumn{2}{c}{ Level 2 } \\
\cline { 2 - 5 } Mengelola & & & PA & PA \\
Keberlanjutan & & & $\mathbf{2 . 1}$ & $\mathbf{2 . 2}$ \\
\hline Rating & $100 \%$ & $87,63 \%$ & $100 \%$ & $92.50 \%$ \\
\hline
\end{tabular}

Tabel 10 menjelaskan bahwa capaian capability level pada level 1 memperoleh skor 87,63\% atau fully achieved sehingga pada proses DSS04 bermakna bahwa implementasi proses pengelolaan keberlanjutan telah berjalan dengan sangat baik sehingga dapat dinyatakan proses DSS pada level 1 sudah tercapai. Oleh karena itu, pengukuran pada DSS04 dapat dilanjutkan ke level 2 yang juga memperoleh penilaian $100 \%$ atau fully achieved pada PA 2.1 yakni dari sisi performance management bermakna bahwa pada seluruh indikator tersebut sudah terpenuhi. Sedangkan pada PA 2.2 yakni work product management memperoleh persentase sebesar $92,50 \%$ atau kembali fully achieved yang mengindikasikan hampir seluruh proses pada atribut tersebut sudah terpenuhi. e. DSS05 - Mengelola Layanan Keamanan

Berdasarakan informasi maupun bukti terhadap setiap sub proses pada masing-masing proses yang ada pada DSS05 mengenai pengelolaan layanan keamanan yang diperoleh dari responden. Hasil penilaian terlihat pada Tabel 11.

Tabel 11. Hasil Penilaian Capability Level 1 Proses DSS05

\begin{tabular}{|c|c|c|c|}
\hline $\begin{array}{l}\text { ID Sub } \\
\text { Proses }\end{array}$ & Nama Sub Proses & Skor & Kondisi \\
\hline DSS05.01 & $\begin{array}{l}\text { Protect against } \\
\text { malware }\end{array}$ & $0 \%$ & $\mathrm{~N}$ \\
\hline DSS05.02 & $\begin{array}{l}\text { Manage network } \\
\text { and connectivity } \\
\text { security }\end{array}$ & $33 \%$ & $\mathrm{P}$ \\
\hline DSS05.03 & $\begin{array}{l}\text { Manage endpoint } \\
\text { security }\end{array}$ & $100 \%$ & $\mathrm{~F}$ \\
\hline DSS05.04 & $\begin{array}{l}\text { Manage user } \\
\text { identity and logical } \\
\text { access }\end{array}$ & $50 \%$ & $\mathrm{~L}$ \\
\hline DSS05.05 & $\begin{array}{l}\text { Manage physical } \\
\text { acces to IT assets }\end{array}$ & $100 \%$ & $\mathrm{~F}$ \\
\hline DSS05.06 & $\begin{array}{l}\text { Manage sensitive } \\
\text { document and } \\
\text { output devices }\end{array}$ & $50 \%$ & $\mathrm{~L}$ \\
\hline DSS05.07 & $\begin{array}{l}\text { Monitor the } \\
\text { infrastructure for } \\
\text { security related } \\
\text { events }\end{array}$ & $0 \%$ & $\mathrm{~N}$ \\
\hline Rerata skor & & $47,57 \%$ & $\mathrm{P}$ \\
\hline
\end{tabular}

Tabel 12. Ringkasan capaian capability level proses DSS05

\begin{tabular}{crrrr}
\hline DSS05 & Level 0 & Level 1 & \multicolumn{2}{c}{ Level 2 } \\
\cline { 2 - 5 } Mengelola & & & PA & PA \\
Layanan & & & $\mathbf{2 . 1}$ & $\mathbf{2 . 2}$ \\
Keamanan & & & \\
\hline Rating & $100 \%$ & $47,57 \%$ & \\
\hline
\end{tabular}

Tabel 12 menjelaskan bahwa capaian capability level pada level 1 memperoleh skor 47,57\% atau partially achieved sehingga pada proses DSS05 bermakna bahwa organisasi belum menjalankan pengelolaan layanan kemanan dengan baik, hal ini tentu akan berdampak buruk mengingat data yang dikelola merupakan data mikro berbasis by name by address seluruh anggota keluarga yang ada di provinsi jawa barat. implementasi proses pengelolaan layanan keamanan yang belum berjalan sesuai harapan dengan baik tersebut sepatutnya menjadi fokus perhatian untuk ditingkatkan.

\section{f. DSS06 - Mengelola Kontrol Proses Bisnis}

Berperan untuk mengelola kontrol proses bisnis yang berfokus pada pendefinisian dan pemeliharaan kontrol proses bisnis. 
Tabel 13. Hasil Penilaian Capability Level 1 Proses DSS06

\begin{tabular}{|c|c|c|c|}
\hline $\begin{array}{c}\text { ID Sub } \\
\text { Proses } \\
\end{array}$ & Nama Sub Proses & Skor & Kondisi \\
\hline DSS06.01 & $\begin{array}{l}\text { Align control activities } \\
\text { embedded in business } \\
\text { processess with } \\
\text { enterprise objective }\end{array}$ & $100 \%$ & $\mathrm{~F}$ \\
\hline DSS06.02 & $\begin{array}{l}\text { Control the processing } \\
\text { information }\end{array}$ & $0 \%$ & $\mathrm{~N}$ \\
\hline DSS06.03 & $\begin{array}{l}\text { Manage roles, } \\
\text { responsibilities, acces } \\
\text { privileges and level of } \\
\text { authority }\end{array}$ & $100 \%$ & $\mathrm{~F}$ \\
\hline DSS06.04 & $\begin{array}{l}\text { Manage errors and } \\
\text { exceptions }\end{array}$ & $100 \%$ & $\mathrm{~F}$ \\
\hline DSS06.05 & $\begin{array}{l}\text { Ensure traceability of } \\
\text { information events and } \\
\text { accountabiities }\end{array}$ & $100 \%$ & $\mathrm{~F}$ \\
\hline DSS06.06 & Secure information assets & $0 \%$ & $\mathrm{~N}$ \\
\hline \multicolumn{2}{|c|}{ Rerata skor } & $66,67 \%$ & $\mathrm{P}$ \\
\hline
\end{tabular}

Tabel 14. Hasil Penilaian Capability Level 1 Proses DSS06

\begin{tabular}{crrrr}
\hline DSS06 & Level 0 & Level 1 & \multicolumn{2}{c}{ Level 2 } \\
\cline { 2 - 5 } Mengelola & & & PA & PA \\
Kontrol & & & $\mathbf{2 . 1}$ & $\mathbf{2 . 2}$ \\
Proses Bisnis & & & & \\
\hline Rating & $100 \%$ & $66,67 \%$ & \\
\hline
\end{tabular}

Tabel 14 menjelaskan bahwa capaian capability level pada level 1 memperoleh skor $66,67 \%$ atau largely achieved sehingga Proses DSS06 bermakna bahwa organisasi telah mengetahui adanya aktivitas teknologi informasi dalam organisasinya dalam hal pengelolaan kontrol proses bisnis. implementasi proses pengelolaan kontrol proses bisnis sebagian besar telah berjalan namun memerlukan perbaikan yang signifikan untuk mencapai harapan yang ditetapkan.

Tabel 15 menunjukkan bahwa terdapat 4 proses yang hanya sampai pada level 1 yaitu pada proses DSS02 (Mengelola Layanan Permintaan dan Insiden), DSS03 (Mengelola masalah), DSS05 (Mengelola layanan keamanan), dan DSS06 (Mengelola control proses bisnis). Hal ini menunjukkan bahwa kedua proses tersebut belum lengkap dan masih jauh dari harapan. Selain itu, terdapat 2 proses yang mencapai pada level 2 yaitu proses DSS01 (Mengelola Operasi) dan DSS04 (Mengelola Keberlanjutan) yang menunjukkan bahwa proses DSS01 dan DSS04 telah mendekati harapan dalam segi pengelolaan operasional.

Tabel 15. Rekap Hasil Penilaian Capability Level

\begin{tabular}{rccc|ccr}
\hline No & $\begin{array}{c}\text { Nama } \\
\text { Proses }\end{array}$ & $\begin{array}{c}\text { Level } \\
\end{array}$ & Level 1 & & Level 2 & \multirow{2}{*}{$\begin{array}{c}\text { Capaian } \\
\text { Level }\end{array}$} \\
\cline { 5 - 6 } & & & & $\begin{array}{c}\text { PA } \\
\text { 2.1 }\end{array}$ & PA 2.2 & \\
\hline 1 & DSS01 & $100 \%$ & $93,40 \%$ & $100 \%$ & $92,50 \%$ & 2 \\
\hline 2 & DSS02 & $100 \%$ & $66.67 \%$ & & & 1 \\
\hline
\end{tabular}

\begin{tabular}{lllllll}
\hline 3 & DSS03 & $100 \%$ & $36,00 \%$ & & & 1 \\
\hline 4 & DSS04 & $100 \%$ & $87,63 \%$ & $100 \%$ & $92,50 \%$ & 2 \\
\hline 5 & DSS05 & $100 \%$ & $47,57 \%$ & & & 1 \\
\hline 6 & DSS06 & $100 \%$ & $66,67 \%$ & & & 1 \\
\hline
\end{tabular}

\section{Analisis GAP}

Analisis GAP digunakan untuk melakukan perbandingan antara tingkat kapabilitas pengelolaan teknologi informasi kondisi existing/saat ini dengan tingkat kapabilitas pengelolaan TI yang diharapkan dengan tujuan memberikan kemudahan dalam perbaikan tata kelola yang ada. Jika hasil analisis GAP menyatakan terdapat kesamaan antara keduanya, maka proses pengelolaan TI dinyatakan sudah berjalan dengan baik. Sebaliknya, jika hasil analisis menyatakan adanya kesenjangan antara tingkat kapabilitas pengelolaan TI existing dengan yang diharapkan maka perlu dilakukan peningkatan terhadap pengelolaan TI agar dapat mencapai tingkat kapablitas yang telah ditentukan Setelah diperoleh nilai capability level, kemudian dilakukan perhitungan dengan menghitung GAP (selisih) antara kondisi existing dengan target yang telah ditentukan oleh organisasi yaitu pada level 3 (tiga) Established Process yang kemudian divisualisasikan kepada grafik radar.

Tabel 16. Perhitungan Analisis GAP

\begin{tabular}{rrrrr}
\hline No & $\begin{array}{c}\text { Nama } \\
\text { Proses }\end{array}$ & $\begin{array}{c}\text { Existing } \\
\text { Level }\end{array}$ & $\begin{array}{c}\text { Target } \\
\text { Level }\end{array}$ & GAP \\
\hline 1 & DSS01 & 2 & 3 & 1 \\
\hline 2 & DSS02 & 1 & 3 & 2 \\
\hline 3 & DSS03 & 1 & 3 & 2 \\
\hline 4 & DSS04 & 2 & 3 & 1 \\
\hline 5 & DSS05 & 1 & 3 & 2 \\
\hline 6 & DSS06 & 1 & 3 & 2 \\
\hline
\end{tabular}

Pada Tabel 16 diperoleh hasil analisis GAP setiap proses pada DSS yang kemudian dapat digunakan untuk menghitung GAP total antara existing level dengan target level dalam rangka mencapai level yang diharapkan dengan menggunakan rumus yang telah dijelaskan dengan perhitungan sebagai berikut:

Capability Level $=\frac{(2 * 2)+(1 * 4)}{6}=1,33$

Perhitungan Capability Level yang diperoleh kemudian menjadi pengurang dari target level yang diinginkan sehingga dapat memunculkan nilai GAP dari Sistem PK dengan penjelasan sebagai berikut:

$G A P=$ Target Level - Capaian Capability Level

Seperti diketahui bahwa target level adalah 3, sedangkan capaian capability level adalah sebesar 1,33 sehingga diperoleh selisih ataupun GAP sebesar 1,67 untuk mencapai level yang diharapkan. Interpretasi dari GAP dimaksud 
dituangkan oleh penulis menggunakan diagram radar seperti pada Gambar 4 berikut.

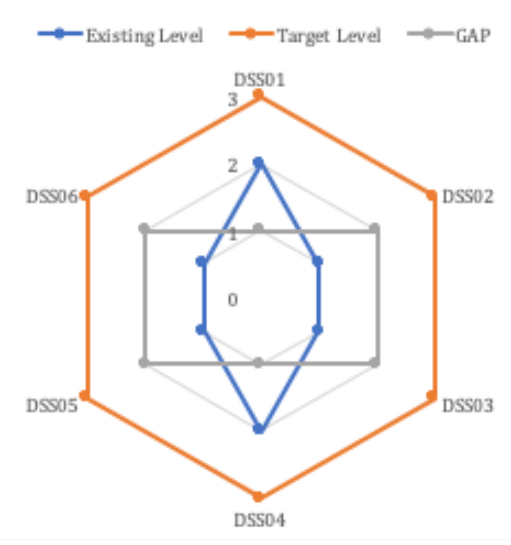

Gambar 4. Grafik Hasil Penilaian Capability Level dan GAP

\section{Rekomendasi}

Dalam melakukan kegiatan evaluasi SI/TI, diperlukan rekomendasi perbaikan agar kekurangan atau kelemahan sumber daya SI/TI organisasi dapat diminimalisir atau bahkan dihilangkan. Dalam upaya ini perlu dilakukan penyempurnaan proses pengelolaan SI/TI yang ada di BKKBN Propinsi Jawa Barat, khususnya Prosedur Operasi Standar (SOP) dalam semua proses yang dilakukan. Berdasarkan analisis GAP yang diperoleh dan ditinjau pada tabel 4 , berikut beberapa rekomendasi yang dirancang untuk meningkatkan kualitas sistem pendataan keluarga di BKKBN Propinsi Jawa Barat pada level 1 yakni:

a) DSS01 - Mengelola operasi, yaitu dengan menyediakan rekaman kegiatan dari insiden yang terjadi secara mandiri atau historical tidak hanya berdasarkan laporan yang diterima.

b) DSS02 - Mengelola permintaan layanan dan insiden, yaitu dengan membuat aturan/pedoman eskalasi insiden, mendokumentasikan report layanan permintaan layanan dan insiden yang telah disetujui dan dipenuhi, menampilkan laporan dari status dan tren insiden, dan memunculkan laporan terhadap status pemenuhan permintaan layanan.

c) DSS03 - Mengelola masalah, yakni dengan menyediakan laporan proses investigasi dan diagnosa masalah yang terjadi, menyediakan laporan penyelesaian masalah yang sudah diketahui, menyampaikan solusi dari permaalahan yang telah diatasi, dan menerapkan manajemen penyelesaian masalah yang bersifat proaktif.

d) DSS04 - Mengelola keberlanjutan dengan mengevaluasi kapabilitas dan kesenjangan proses bisnis saat ini, membuat analisis dampak terhadap proses bisnis, dan mengkaji hasil pengujian dan rekomendasi yang didapatkan.

e) DSS05 - Mengelola layanan kemanan dengan melindungi sistem Pendataan Keluarga dari serangan malware, meningkatkan Pengelolaan keamanan jaringan dan konektivitas infrastruktur TI, mengelola daftar permintaan hak akses yang disetujui, menyediakan log peristiwa kemanan (event security log), serta memonitoring infrastruktur TI yang berhubungan dengan keamanan.

f) DSS06 - Mengelola kontrol proses bisnis dengan menyediakan laporan dari kontrol pengolahan informasi, dan meningkatkan ketersediaan penelusuran peristiwa informasi.

Setelah indikator pada level 1 diatas disempurnakan atau ditingkatkan. Maka untuk mencapai kemampuan level 2, seluruh proses terpilih harus memenuhi dan melaksanakan indikator kerja sebagai berikut ini:

a) Indikator Performance management pada level 2 PA2.1 sudah terpenuhi karena penilaian Capability Level mendapatkan hasil $100 \%$, termasuk ke dalam rentang Fully Achieved.

b) Indikator Work Product Management dengan meningkatkan persyaratan dari proses sudah didefinisikan, hal ini ditandai dengan adanya perencanaan kualitas yang baik, serta Work product yang dihasilkan dikaji sesuai dengan perencanaan dan persyaratan yang diharapakan secara optimal.

Jika indikator pada level 1 dan level 2 telah disempurnakan. Maka untuk mencapai level 3, seluruh proses terpilih harus memenuhi dan melaksanakan indikator kerja sebagai berikut:

a) Indikator Process Definition yakni standar dalam proses sudah tersedia yang dilengkapi dengan panduan-panduan untuk modifikasi, terdapat standar urutan dan cara interaksi diantara sub-proses atau proses lainnya, adanya standar penilaian terhadap kompetensi dan peran untuk menjalankan proses TI, adanya standar penilaian terhadap infrastruktur dan lingkungan kerja untuk menjalankan proses TI, serta adanya pengawasan efektifitas proses yang sesuai dengan proses TI.

b) Indikator Process Deployment yakni seluruh proses yang berjalan dipastikan berdasarkan kepada standar yang telah ditentukan, memetakan peran, tanggung jawab, dan otoritas untuk menjalankan proses yang telah didefinisikan, memastikan penempatan SDM sesuai dengan kebutuhan kompetensi yang diperlukan, menyediakan sumber daya dan informasi untuk mendukung performa dari proses yang didefinisikan, menyediakan infrastruktur yang layak untuk mendukung, serta mengumpulkan dan menganalisis data mengenai performa dari proses untuk mengukur kecocokan dan keefektifan.

\section{KESIMPULAN}

Berdasarkan hasil analisis terhadap domain DSS yang telah dilakukan, terdapat 2 Proses yang berhasil mencapai level 2 yaitu pada proses DSS01 (mengelola operasi) dan DSS04 (mengelola keberlanjutan) yang menunjukkan bahwa BKKBN belum sepenuhnya mengimplementasikan proses TI maupun tujuan dari proses TI yang telah ditentukan.

Berdasarkan hasil analisis terhadap domain DSS yang dilakukan, terdapat 4 Proses yang berada pada level 1 yaitu pada proses DSS02 (mengelola layanan dan permintaan 
insiden), DSS03 (mengelola masalah), DSS05 (mengelola layanan keamanan), dan DSS06 (mengelola kontrol proses bisnis) yang menunjukkan bahwa BKKBN perlu meningkatkan proses-proses tersebut terutama pada DSS05 dalam hal layanan keamanan mengingat data mikro kependudukan yang disimpan bersifat rahasia.

Terdapat GAP yang cukup signifikan antara tingkat kapabalitas pengelolaan TI saat ini dengan yang diharapkan pada tahun 2020 yaitu sebesar 1,67 dengan komposisi 2 proses memiliki GAP sebesar 1 dan 4 proses lainnya sebesar 2. Hal tersebut menunjukkan bahwa pengelolaan sumber daya TI yang dilakukan masih jauh atau belum selaras dari yang diharapkan.

Dari seluruh rangkaian penelitian yang telah dilakukan di BKKBN Propinsi Jawa Barat dapat disimpulkan bahwa diperoleh nilai level kapabilitas sebesar 1,33 dan terdapat gap sebesar 1,67 untuk mencapai level yang diharapkan.

\section{DAFTAR PUSTAKA}

[1] Directorate of Reporting and Statistics. (2018). Profile of Indonesian Families 2018. Jakarta: Directorate of Reporting and Statistics BKKBN RI.

[2] Swastika, I.P.A., \& Putra, I.G.L.A.R. (2016). Audit Sistem Informasi dan Tata Kelola Teknologi Informasi:
Informasi dan Studi Kasus. Yogyakarta: ANDI.

[3] Andry, J.F. (2016). Audit of IT Governance Based on COBIT 5 Assessments: A Case Study. Jurnal Nasional Teknologi \& Sistem Informasi, Vol. 2(2), pp. 27-34.

[4] Spremic, M., Ivanov, M. \& Jakovic, B. (2012). IT Governance and Information Sistem Auditing Practice in Credit Institutions in The Republic of Croatia. International Journal of Applied Mathematics and Informatics, Vol. 6(2): pp. 101-108.

[5] Svata, V. (2011). IS Audit Considerations in Respect of Current Economic Environment. Journal of Systems Integration, Vol. 2(1), pp. 12-20.

[6] ISACA. (2012). COBIT 5: Personal Assesment Model.

[7] Al-Rasyid, A. (2105). Analisis Audit Sistem Informasi Berbasis COBIT 5 Pada Domain Deliver, Service, and Support (DSS) (Studi Kasus: SIM-BL di Unit CDC PT Telkom Pusat. Tbk) [Skripsi]. Universitas Telkom.

[8] Kusumasindra, F. (2013). Audit Tata Kelola Teknologi Informasi Menggunakan Framework COBIT 5 pada Domain Delivery, Service dan Support di Institut Manajemen Telkom [Skripsi]. Universitas Telkom.

[9] Rozas, I.S. \& Effendy, D.A. (2012). Mengukur Efektifitas Hasil Audit Teknologi Informasi COBIT 4.1 Berdasarkan Perspektif End User. Jurnal Link, Vol. 17(2), pp. 1-5.

[10] ISACA. (2012). COBIT 5: Enabling Process. 